\title{
Hve mikil eru staðkvæmdaráhrif í vísitölu neysluverðs á Íslandi?
}

\begin{abstract}
Kári Joensen
Ágrip: Í greininni er fjallað um pá erfiðleika sem fylgja pví að mæla framfærslukostnað með vísitölu neysluverðs, sér í lagi vanda vegna staðkvæmdaráhrifa, og fjallað er um mat sem aðrar pjóðir hafa gert á stærðargráðu pessa bjaga. Í greininni er ennfremur fjallað um pá pætti sem helst valda staðkvæmdaráhrifum og hvort aðstæður á Íslandi gefi ástæðu til að ætla að vandinn sé umfangsmeiri hér en annars staðar. Pví er gerður samanburður á aðferðum Hagstofu Íslands og annarra hagstofa í Evrópu við mat á vogum og fjallað um leiðir til að draga úr staðkvæmdaráhrifum.
\end{abstract}

Lykilorð: vísitala neysluverðs; staðkvæmdaráhrif; hagmælingar

\begin{abstract}
This paper focuses on the difficulties of measuring the cost of living with a consumer price index, particularly those due to substitution effects, and reviews estimates of the degree of substitution bias. The paper examines the causes of the bias and looks at the evidence for the claim that its magnitude is greater in Iceland's CPI than elsewhere. In the process, the methodologies for index weight estimation used by Statistics Iceland and by a few other European statistical agencies are compared, and ways to minimize the bias are reviewed.
\end{abstract}

Keywords: consumer price index; substitution effect; econometrics

\section{Inngangur}

Verðvísitölur sem reiknaðar eru með Laspeyres formúlu eða öðrum skyldum formúlum ofmeta áhrif verðhækkana á verðlag og vanmeta verðlækkanir (Aizcorbe og Jackman, 1993). Pessi bjagi (e. bias) í mati á verðlagsbreytingum hefur lengi verið mönnum ljós og til að lágmarka staðkvæmdaráhrif á verðvísitölur er ýmsum ráðum beitt. Pættir sem hafa áhrif á pennan bjaga eru pekktir og pví má draga ályktanir um umfang hans, t.d. hér á landi, í samanburði við önnur lönd. Tiltölulega lítill verðstöðugleiki á Íslandi gefur tilefni til að ætla að staðkvæmdaráhrif séu meiri hér en ella en hins vegar kemur margt fleira til og í pessari grein eru færð rök fyrir pví að líklega séu staðkvæmdaráhrif á vísitölu neysluverðs ekki meiri hér á landi en gengur og gerist.

Undanfarið hefur heyrst gagnrýni á útreikning vísitölu neysluverðs hérlendis í pá veru að ekki sé tekið nægt tillit til breytinga sem orðið hafa á neyslu heimila og að mæld verðbólga sé pví hærri en raunveruleg verðbólga. Á árinu 2008 urðu mikil 
efnahags- og fjármálaáföll á Íslandi sem höfðu í för með sér skarpa breytingu á einkaneyslu (Rannsóknasetur verslunarinnar, 2009). Útbreiðsla verðtryggðra skuldbindinga er mikil meðal íslenskra heimila og eru verðlagsmál jafnan ofarlega á baugi. Verðbólga jókst verulega á árinu 2008 en á sama tíma fór að heyrast gagnrýni á aðferðir við mælingu verðbólgunnar og umræða vaknaði um pær vogir sem vísitalan byggir á og hvort mæld verðbólga sé sú sem neytendur búa raunverulega við.

Í pessari grein er fyrst fjallað um gerð voga fyrir vísitölu neysluverðs og samspil aðferðafræðinnar við umfang bjaga vegna staðkvæmdaráhrifa. Pví næst eru aðferðir nokkurra evrópskra hagstofa við reikning vísitölunnar bornar saman og loks er litið til megindlegra rannsókna á umfangi bjagans til að álykta um stærð hans hérlendis.

\section{Grunnur vísitölu neysluverðs}

Vísitala neysluverðs mælir meðalverðbreytingu á neysluvörum heimilanna frá einum mánuði til annars. Vísitalan mælir pannig verðlag einkaneyslu en einkaneysla er samandregið verðmæti útgjalda heimilanna vegna kaupa eða nota á vörum og pjónustu (Hagstofa Íslands, 2008a). Að grunni til er hugmyndin pví sú að vega saman í eina stærð verðbreytingar á ólíkum vörum (hér eftir er orðið vörur notað pó að bæði sé átt við vörur og pjónustu) eftir vægi peirra í neyslu heimilanna. Til að pað sé hægt parf upplýsingar um bæði verð og magn peirra vara sem heimilin neyta á hverjum tíma en slík altæk gagnasöfnun er augljóslega óraunhæfur kostur. Pess í stað eru gerðar úrtakskannanir, ein par sem verðupplýsingum er safnað saman og önnur par sem vogirnar eru metnar. Vogir verðvísitölu eru vektor sem sýnir hlutfallslegt vægi hverrar vöru í verðvísitölunni og skulu vogirnar endurspegla neyslusamsetningu heimilanna hverju sinni eins vel og kostur er. Miklu máli skiptir að pessi könnun sé ítarleg og gefi par með raunhæfa mynd af neyslusamsetningu heimilanna. Verðupplýsingum er svo safnað saman í hverjum mánuði og vogirnar notaðar til að vega verðbreytingar saman. Við útreikning vísitölunnar er henni skipt í tvö aðgreind lög, efra lag og neðra lag. Í efra lagi eru vegnir saman ólíkir vöruflokkar, t.d. húsnæði, mat- og drykkjarvara, föt og skór. Í neðra lagi eru pessir yfirflokkar svo greindir í sundur með nákvæmari hætti, allt niður í einstaka vörur. Með framfærsluvísitölu (e. cost-of-living index) fæst mat á pví hversu mikið lágmarks útgjöld purfa að breytast til pess að tilteknum lífskjörum (e. standard of living) sé viðhaldið pó að verð hafi breyst frá einum tíma til annars (Boskin o.fl.,1996). Vísitalan mælir hins vegar ekki hvort útgjöld heimilanna séu að aukast eða hvort neysla sé meiri eða minni en áður. Pað er einfaldlega ekki tilgangur vísitölunnar og til að svara slíkum spurningum parf að mæla magn neyslunnar til viðbótar við verðið en vísitala neysluverðs mælir breytingar á verðlagi einkaneyslu.

Hér á landi er gerð vísitölu neysluverðs að öllu leyti í höndum Hagstofu Íslands en pað er sama fyrirkomulag og pekkist í löndunum í kring. Í hverjum mánuði safnar Hagstofan saman ítarlegum upplýsingum um verð neysluvara hérlendis. Verðsöfnunin fer jafnan fram um miðjan hvern mánuð og er vísitalan svo birt samkvæmt út- 
gáfuáætlun, par sem miðað er við að birting sé eigi síðar en næstsíðasta virkan dag viðkomandi mánaðar. Verðupplýsingum er safnað saman með ýmsum hætti, t.d. með verðsöfnun í verslunum, en Hagstofan fær einnig upplýsingar um verð frá söluaðilum gegnum símtöl, tölvupóst og símbréf. Í hverjum mánuði safnar Hagstofan yfir 20.000 verðmælingum fyrir ríflega 4.000 ólíkar vörur (Hagstofa Íslands, 2008a).

Upplýsingum um vogir fyrir vísitölu neysluverðs er safnað saman með öðrum hætti. Hagstofan framkvæmir árlega útgjaldarannsókn til að meta vægi vöruflokkanna í útgjöldum heimilanna. Heimilin í úrtakinu gera svokallaðan búreikning sem er ítarleg sundurliðun á útgjöldum pess heimilis í tvær vikur í senn. Rannsóknin stendur yfir allt árið til að koma í veg fyrir árstíðartengdar skekkjur í matinu og er hverju ári skipt niður í 26 búreikningstímabil og könnunum haldið úti á hverju peirra. Útgjöldum heimila má skipta í reglubundin útgjöld, eins og kaup á mat og annarri dagvöru, og óreglubundin útgjöld eins og t.d. kaup á bifreiðum, húsgögnum og stærri heimilistækjum. Til pess að fá betri mynd af óreglubundnu útgjöldunum svara heimilin í úrtakinu könnun um slík innkaup fyrir priggja mánaða tímabil til viðbótar við tveggja vikna búreikninginn. Pegar vogir eru svo metnar út frá pessum könnunum er byggt á niðurstöðum priggja ára í senn til að draga enn frekar úr úrtaksskekkju. Útgjaldarannsókn ársins 2006 var pannig tekin í vogir vísitölunnar í mars árið 2008 ásamt niðurstöðum fyrir 2004 og 2005 (Hagstofa Íslands, 2008b). Svo er sú elsta alltaf felld út pegar ný er tekin inn pannig að niðurstöður fyrir 2006 falla út í mars 2011. Pessi útgjaldarannsókn er mikilvægasta heimildin fyrir mat á vogum neysluverðsvísitölunnar en auk hennar eru gögn úr ýmsum áttum notuð par sem pví verður komið við. Til slíkra ráða er t.d. gripið pegar ljóst pykir að neysla tiltekins vöruflokks hafi breyst verulega frá pví pegar vogin var metin og par til hún er tekin til notkunar. Má par nefna upplýsingar um nýskráningar bíla sem safnað er saman mánaðarlega af Umferðarstofu og við mat á húsnæðislið vísitölunnar er stuðst við mánaðarlegar tölur frá Fasteignamati ríkisins (Hagstofa Íslands, á.á.). Nú er einnig unnið að pví að meta sölu á pakkaferðum til útlanda frá ferðaskrifstofum, enda snarbreyttist eftirspurn eftir peim á haustmánuðum ársins 2008. Petta eru pýðingarmiklir vöruflokkar í vísitölunni og sem dæmi má nefna að í janúar 2009 vó húsnæðisliðurinn 23,3\% í vísitölunni og flokkurinn „Nýr bíll og varahlutir“ vó 8,3\%. Í úrtaki pessarar könnunar voru síðast 1.603 heimili sem hvert og eitt skila inn ítarlegum upplýsingum um útgjöld sín til Hagstofunnar (Hagstofa Íslands, 2009).

Pegar valin er útreikningsaðferð fyrir verðvísitölu eins og vísitölu neysluverðs valda gæði upplýsinganna pví að gera parf ýmsar einfaldanir eða nálganir. Í flestum tilfellum er markmiðið að komast sem næst gildi svokallaðrar Laspeyres vísitölu. Formúlan fyrir Laspeyres vísitölu er

$$
P_{L}\left(p_{0}, p_{t}, q_{0}\right)=\frac{\sum_{n=1}^{N} p_{n}^{t} q_{n}^{0}}{\sum_{n=1}^{N} p_{n}^{0} q_{n}^{0}}
$$


par sem $p^{0}$ er verð vöru á tíma $t=0$ og $p^{t}$ er verð vörunnar á tíma $t$ par sem $t$ er jafnan stærra en núll. Vektorinn $p^{0}$ hefur $n$ stök par sem $n$ er fjöldi ólíkra vara í vörusafninu og $q^{0}$ er magn hverrar vöru á tíma $t=0$. Með formúlunni er pví reiknað verðmæti fastrar vörukörfu á tveim ólíkum tímum og hlutfall stærðanna tveggja gefur einingalausa stærð sem lýsir hlutfallsbreytingu vísitölunnar frá tíma 0 til $t$. Til að reikna pessa vísitölu purfa að liggja fyrir upplýsingar um neyslusamsetningu á tíma $t=0$ en par sem áđurnefndar útgjaldarannsóknir eru jafnan ekki framkvæmdar nema árlega fæst ekki uppfært mat á vektornum $q^{0}$ nema einu sinni á ári. Verðbreytingarnar eru aftur á móti metnar mánaðarlega og til að meta verðbólgu (par sem verðbólga er skilgreind sem árshækkun vísitölu neysluverðs) pá er horft til hlutfallslegrar breytingar frá einum mánuði til sama mánaðar næsta árs, p.e.

$$
\frac{P_{L}\left(p_{0}, p_{t}, q_{0}\right)}{P_{L}\left(p_{0}, p_{t-12}, q_{0}\right)}=\frac{\sum_{n=1}^{N} p_{n}^{t} q_{n}^{0}}{\sum_{n=1}^{N} p_{n}^{t-12} q_{n}^{0}}
$$

sem er Lowe vísitala, táknuð $P_{L o}\left(p_{t-12}, p_{t}, q_{0}\right)$. Pessi nálgun að Laspeyres vísitölunni er algeng í einni eða annarri mynd pegar vísitala neysluverðs er reiknuð. Verðbreyting er metin frá einum mánuði til sama mánaðar næsta árs en magnvektorinn er metinn yfir annað tímabil sem nær jafnvel yfir heilt ár, fyrr í tíma en $t-12$ og $t$. Gera verður pann fyrirvara að Lowe vísitöluformúlan lýsir aðeins á mjög einfaldan hátt grunnuppsetningu vísitölu neysluverðs og í reynd er útreikningurinn mun margpættari og ekki einsleitur pegar horft er á ólíka vöruflokka innan vísitölunnar. Á pað við um framkvæmd útreikningsins hérlends sem og annars staðar.

Haustið 2008 urðu miklar breytingar á innlendri eftirspurn í kjölfar efnahagsáfalla sem dundu yfir. Fasteignaverð var tekið að lækka eftir margra ára stöðugar verðhækkanir en verðbólga var á sama tíma um 15\% og hafði ekki sést jafn há síðan 1990. Í kjölfarið fór af stað umræða um gæði vísitölu neysluverðs sem almenns verðlagsmælikvarða. Gagnrýni spratt upp í kjölfar pess að vísitalan hækkaði verulega hratt á haustmánuðum 2008 á sama tíma og neysla dróst saman og neyslusamsetning breyttist. Gagnrýnin hefur verið misvel rökstudd og pví er fljótsvarað að ekkert er óeðlilegt við pað að verðbólga mælist há pegar neysla dregst saman pví að vísitalan mælir verðbreytingar neysluvara en ekki magnbreytingar. Einnig var gagnrýnt að verðhækkanir á vörum, sem ekki var neytt í eins miklum mæli og áður, hefðu samt talsvert vægi í vísitölunni og pví áhrif á mælda verðbólgu. Peim hugmyndum sem búa að baki slíkri gagnrýni er auðvelt að lýsa með hliðsjón af Lowe vísitöluformúlunni. Pá er jafnan bent á pað að í vísitölunni eru vegnar saman verðbreytingar frá tíma $t-12$ til $t$ en vogin er metin yfir tímabil sem lýkur á tíma 0 par sem $0<t-12<t$. Pegar verðhlutföll á tíma $t$ hafa breyst mikið frá pví vogin var metin er líklegt að neyslusamsetningin sé orðin önnur. Peirra vara sem hækkað hafa mest er neytt í minna magni á tíma $t$ en pví sem vektorinn frá tíma 0 segir til um. Einnig ætti neysla peirra vara sem minna hafa hækkað að vera orðin hlutfallslega meiri og pví fá vörurnar sem hækkað hafa mest í verði of hátt vægi í vísitölunni. Pessi gagnrýni er í 
grundvallaratriðum réttmæt en aðeins er hálf sagan sögð ef ekki er síðan litið til pess hvernig hægt er að bregðast við pessum vanda, hvort pað sé gert, og hve mikil skekkjan er pá í raun og veru.

\section{Hvað eru staðkvæmdaráhrif?}

Verðhlutföll ólíkra vara breytast í sífellu enda myndast kostnaður við framleiðslu á ólíkan hátt. Pegar verð einnar vöru hækkar umfram verð annarra bregðast neytendur við með pví að draga úr neyslu peirrar vöru. Segja má að pessi samdráttur í neyslu stafi af áhrifum tveggja pátta sem verka á neytendur, annars vegar tekjuáhrifum og hins vegar staðkvæmdaráhrifum. Tekjuáhrifin stafa af pví að verðlag hefur hækkað, pannig að framfærsla er orðin dýrari en hún var, á sama tíma og laun standa í stað. Niðurstaðan er pví raunlækkun launa sem veldur minni neyslu á vörum í heild. Staðkvæmdaráhrifin verða til af pví að eftir að verð pessarar einu vöru hækkaði pá breyta neytendur neyslu sinni með pví að velja aðrar vörur í stað hennar. Ein vara er sögð vera staðkvæmdarvara annarrar ef neytandinn er tilbúin að neyta annarrar vörunnar í stað hinnar. Sem dæmi má hugsa sér að kjöt sé staðkvæmdarvara fyrir fisk. Pegar verð einnar vöru hækkar og sú vara á sér einhverja staðkvæmdarvöruvelur neytandinn staðkvæmdarvöruna í meira mæli en ella á kostnað peirrar sem hækkaði. Pannig breytist neyslusamsetninginsökum pessara síðarnefndu áhrifa sem við nefnum staðkvæmdaráhrif. Til dæmis gæti hækkun á verði fersks fisks leitt til pess að neytandi velji að draga úr fiskneyslu og kaupi frekar kjöt.

Eins og hér hefur verið fjallað um er verðbólga metin með pví að mæla verðbreytingu ólíkra vara og vega svo pessar breytingar saman eftir pví hvað vörurnar eiga stóra hlutdeild í heildarútgjöldum neytenda. Sökum pess hvað rannsóknir á neyslusamsetningu eru dýrar og tímafrekar pá er pað almennt svo að mat á vogum er eldra en mat á verðbreytingum. Pegar vandamálið við gerð verðvísitölu er nálgast með efnahagslegri aðferð (e. economic approach) fremur en prófunaraðferð (e. test approach eða axiomatic approach) gerum við ráð fyrir að neytendur bregðist við verðbreytingum og velji hverju sinni pá neyslusamsetningu sem hámarkar nytjafall peirra með tilliti til vöruverðs og útgjaldatakmarka hvers og eins. Pegar verð einnar vöru hækkar umfram verð annarra minnkar neysla á peirri vöru en vog hennar í vísitölunni er ekki uppfærð jafnóðum heldur er vægi vörunnar metið yfir tímabil sem er liðið pegar verðið hækkar. Vægi vörunnar í heildarneyslu verður pví ofmetið pegar vísitalan er reiknuð og áhrif verðhækkunarinnar á heildarverðlag verður meira en pað ætti að vera. Pegar hið gagnstæða gerist, p.e. að verð einnar vöru lækkar skyndilega umfram önnur verð, eykst neysla peirrar vöru á kostnað annarra en varan verður pá vanmetin í voginni fyrir verðvísitöluna pví að vogirnar eru ekki endurmetnar jafn ört og sjálft verð varanna. Niðurstaðan er pví sú að ef vísitala neysluverðs er reiknuð með Laspeyres formúlu (eða Lowe formúlu) pá ofmetur sú vísitala hækkun framfærslukostnaðar. Hliðstæð vísitöluformúla, par sem vogir eru metnar á sama tíma og seinna verðið í Laspeyres formúlunni, nefnist Paasche formúla, 


$$
P_{P}\left(p_{0}, p_{t}, q_{t}\right)=\frac{\sum_{n=1}^{N} p_{n}^{t} q_{n}^{t}}{\sum_{n=1}^{N} p_{n}^{0} q_{n}^{t}}
$$

og með sambærilegri röksemdafærslu og áđur má sýna fram á að slík vísitala vanmetur hækkun á framfærslukostnaði og ofmetur lækkun hans. Paasche vísitalan gefur pannig neðri mörk á breytingu framfærslukostnaðar á meðan Laspeyres vísitalan gefur efri mörk. Æskileg formúla er sú sem notar einhvers konar meðaltal voganna á tímum 0 og $t$. Ýmsar leiðir hafa verið skoðaðar við að reikna pessar vogir og sú formúla sem er hvað pekktust peirra er Fisher vísitöluformúlan sem reiknar margfeldismeðaltal Laspeyres og Paasche formúlanna

$$
P_{F}=\sqrt{P_{L} P_{P}}
$$

en af öðrum útgáfum á nefna Törnqvist-vísitölu og Walsh-vísitölu (Rósmundur Guðnason, 2004). Pessar prjár vísitölur tilheyra flokki afburðarvísitalna (e. superlative index number) par sem pær uppfylla viss stærðfræðileg skilyrði (Diewert, 1976). Fisher vísitalan er pví ákjósanlegur kostur par sem hún á annað borð kemur til greina en vandinn er sá að til pess að reikna Paasche vísitölu fyrir tíma $t$ (og síðan Fisher vísitölu) parf að safna upplýsingum um vogir á tíma $t$. Pegar markmiðið er að birta svo niðurstöðu innan sama mánaðar, og jafnvel pó birting væri innan næsta mánaðar, pá reynist petta mat á vogum óframkvæmanlegt með góðu móti, nema fyrir örfáa vöruflokka. Veruleikinn er pví sá að við útreikning á neysluverðsvísitölu, t.d. frá tíma 0 til $t$, pá er stuðst við vogir, hvorki frá tíma 0 né $t$ heldur fyrr. Vogirnar eru metnar yfir tímabil sem er allt eldra en fyrra verðið frá tíma 0 og pví er jafnan notast við Lowe formúlu. Hins vegar er raunhæft verkefni að reikna afburðavísitölur með meiri tímatöf, nokkur ár eða áratugi aftur í tímann. Pá er augljóslega ekki um að ræða vinnslu á skammtímahagtölum til mats á efnahagsástandi heldur getur slík vinna varpað ljósi á pað hve vel tókst til við að meta breytingar á framfærslukostnaði með peim upplýsingum sem voru fyrir hendi á peim tíma sem pær voru birtar. Pannig má nálgast tölulegt mat á bjaga vegna staðkvæmdaráhrifa fyrir tiltekið tímabil.

\section{Hvað hefur áhrif á stærðargráðu bjagans?}

Í pessari grein er athyglinni fyrst og fremst beint að staðkvæmdaráhrifum og pví hve mikið pau skekkja mat á vísitölu neysluverðs. Stærðargráða pessarar skekkju fer eftir ýmsum páttum sem geta verið ólíkir milli landa. Í fyrsta lagi má benda á pað að eftir pví sem verðsveiflur eru meiri má ætla að staðkvæmdaráhrifin verði meiri. Af pví leiðir að bjagi vegna staðkvæmdaráhrifa er líklega minni í löndum par sem verðbólga mælist jafnan lág, p.e. par sem verðlag er stöðugt. Petta skýrist einfaldlega af pví að við slíkt ástand verðstöðugleika breyta heimilin ekki neyslu sinni jafn ört og ella svo að vogirnar sem vísitalan er byggð á úreldast ekki jafn hratt. Hárri verðbólgu fylgir gjarnan einnig tiltölulega hröð breyting á verðhlutföllum. Petta á sér í lagi við um lönd par sem áhrif gengisbreytinga á innlent verðlag eru mikil og er Ísland gott dæmi 
um slíkt land. Par sem talsverður hluti neysluvara hérlendis er innfluttur og pví verðlagður í annarri mynt en íslenskum krónum hafa sveiflur í gengi krónunnar fljótt áhrif á innlent verðlag. Falli gengi krónunnar umtalsvert á skömmum tíma veldur pað hækkun á verði innfluttra neysluvara en kostnaður við innlenda framleiðslu hækkar ekki jafn hratt. Pessar innlendu framleiðsluvörur geta verið staðkvæmdarvörur fyrir pær innfluttu og pegar verðhlutföllin breytast hratt auka heimilin neyslu á innlendu vörunum á kostnað peirra innfluttu. Á skömmum tíma breytist pá neyslan talsvert en grunnur vísitölunnar er eins og fram hefur komið aðeins endurmetinn einu sinni á ári og pá með hliðsjón af gögnum sem gætu hafa verið tekin saman áður en slíkt gengisfall varð.

Annar páttur sem ræður skekkjunni vegna staðkvæmdaráhrifa er framboð staðkvæmdarvaranna. Oft er erfitt fyrir neytandann að finna vöru sem virkar sem staðkvæmdarvara fyrir pá sem hann neytir nú pegar. Petta á sér í lagi við um pjónustu af ýmsu tagi pví að pjónustu sem slíka er oft ekki hægt að flytja á milli staða á sama hátt og vörur. Framboð staðkvæmdarvara er pví meira pegar um er að ræða ápreifanlegar vörur sem hægt er að flytja til að geyma í birgðum og pess vegna eru staðkvæmdaráhrif meiri innan slíkra vöruflokka. Húsnæði er einnig dæmi um vöruflokk sem ekki verður fyrir miklum staðkvæmdaráhrifum. Neytendur kaupa eða leigja húsnæði til að hafa af pví pjónustu, p.e. að hafa pak yfir höfuðið. Hækki leiguverð mikið myndast hvati til að draga úr neyslu á húsnæði en vandinn er að góða staðkvæmdarvöru er erfitt að finna. Рað er tiltölulega dýrt og tímafrekt að skipta um húsnæði öfugt við pað að velja t.d. aðra matvöru en áður. Einnig er líklegt að húsnæði með sömu eiginleika, t.d. svipaða stærð og staðsetningu, verði fyrir sambærilegum verðbreytingum svo ávinningurinn, og par með hvatinn til að skipta, verður enginn. Hlutfallsleg breyting á húsnæðiskostnaði er pví tiltölulega lengi að koma fram sem breyting á neyslu húsnæðis.

Gerðar hafa verið rannsóknir á sambandi milli pess hve oft vogir neysluverðsvísitölu eru endurmetnar og hver stærðargráða staðkvæmdaráhrifanna er. Tilgátan er pá sú að pví eldri sem vogirnar eru pví meiri ættu staðkvæmdaráhrifin að vera. Ef langur tími líður frá pví að vogir voru metnar má ætla að breytt verðhlutföll hafi valdið breytingum á neyslu sem vogirnar ná ekki að endurspegla. Hið sama má segja um aðstæður pegar verðbólga er mikil pví að svo lengi sem verðbólga er ólík meðal ólíkra vörutegunda breytast verðhlutföll hratt á slíkum tímum. Рað er pví samspil pessara tveggja pátta sem horfa parf til pegar lagt er mat á möguleg staðkvæmdaráhrif. Niðurstöður eru ekki á einn veg. Dæmi eru um rannsóknir sem benda ekki til pess að áhrifin aukist eftir pví sem vörukarfan sem notuð er eldist og ekki finnast merki um pað að neysluverðsvísitala mælist kerfisbundið lægri ef oftar er skipt um grunn hennar (Greenlees, 1998). Að hluta má rekja pessa niðurstöðu til pess að neytendur eiga oft auðvelt með að finna staðkvæmdarvörur fyrir pær sem hafa hækkað í verði pegar horft er á vörur innan sama flokks (t.d. staðkvæmd milli tegunda af drykkjarvörum) en finna síður staðkvæmdarvörur milli flokka. Sem dæmi um stað- 
kvæmdarvörur í ólíkum flokkum má nefna rekstur eigin bifreiðar og pjónustu almenningssamgangna. Neytendur geta valið að nota almenningssamgöngur í meiri mæli ef kostnaður við rekstur bifreiðar hækkar mikið. Nokkur munur er engu að síður á peirri pjónustu sem peir velja pá á milli og almennt má segja að skipting milli flokka í efra lagi vísitölunnar gerist ekki eins hratt og í neðra laginu (Schmidt, 1995). Staðkvæmdaráhrif koma pví fyrr fram í neðra lagi vísitölunnar en par er svo að mestu ráðin bót á vandanum með notkun réttra reikniaðferða sem lýst er síðar. Bæði Greenlees (1998) og Schmidt (1995) komast að pví að lengd tímabilsins frá pví að vogir vísitölunnar voru metnar skipti litlu máli en rannsóknir annarra hafa sýnt fram á hið gagnstæða. Til dæmis má nefna grein Balk og Diewert (2003) par sem metin eru staðkvæmdaráhrif Lowe vísitölu. Par er sýnt fram á að bjagi vegna staðkvæmdaráhrifa er alla jafnan til staðar í Lowe gerð af vísitölum en að pennan bjaga megi lágmarka með pví að minnka tímatöfina í vogum vísitölunnar og með pví að uppfæra vogirnar sem oftast. Sú niðurstaða kemur heim og saman við pá mynd sem dregin er upp af vandanum ef fjallað er um hann út frá hagrænni aðferð, par sem gert er ráð fyrir pví að neytendur velji pær vörur sem peir kaupa með hliðsjón af nytjafalli sem peir reyna að hámarka. Vandinn er hins vegar sá að útgjaldarannsóknir eru mjög dýrar í framkvæmd og peim sem framleiða pessar hagtölur eru væntanlega alltaf einhverjar skorður settar í peim efnum.

Árið 1995 setti öldungadeildarping Bandaríkjanna á fót nefnd til að rannsaka umfang bjaga í vísitölu neysluverðs par í landi. Pá var mönnum ljóst að vegna pess að vísitalan ofmat verðhækkanir höfðu verðtryggðar greiðslur út úr félagslega kerfinu vaxið umfram verðlag og kostnaður ríkisins vegna pessara hækkana umfram umsamdar hækkanir hljóp á milljörðum dollara ár hvert. Pví var sett á fót nefnd til að meta umfang pessa bjaga og benda á úrbætur. Í skýrslu nefndarinnar, sem jafnan er nefnd Boskin skýrslan (kennd við formann nefndarinnar, Michael J. Boskin), var hækkun á vísitölu neysluverðs vegna bjaga metin 1,1\% á ári. Par af voru staðkvæmdaráhrif 0,4\% sem skiptast í áhrif á efra lag vísitölunnar upp á 0,15\% og á neðra laga vísitölunnar upp á 0,25\%. Í kjölfarið á vinnu pessarar nefndar var gerð sú breyting að tekin var upp ný aðferð við útreikning í neðra lagi vísitölunnar par sem stuðst var við margfeldismeðaltal. Jevons vísitöluformúlan er dæmi um formúlu sem byggir á margfeldismeðaltali verðhlutfalla og er notuð til að reikna verðbreytingar í neðsta lagi neysluverðsvísitölu. Með formúlunni er reiknað óvegið margfeldismeðaltal og með pví er gengið út frá pví að vogir séu jafnar pó að verðhlutföll breytist. Sú forsenda heldur ef vörurnar sem um ræðir hafa einingarteygni pannig að ef verð einnar vöru hækkar pá lækkar neysla hennar hlutfallslega jafn mikið og hlutdeild vörunnar í vörukörfunni helst óbreytt (Dalton, Greenlees og Stewart, 1998). Formúla sem pessi hentar ekki vel fyrir efri flokka vísitölunnar pví að par eru vegnar saman vörur sem innbyrðis eru ekki góðar staðkvæmdarvörur, t.d. húsnæði og húsgögn. En fyrir flokka í neðra lagi vísitölunnar er eðlilegt að gera ráð fyrir pví að neytendur bregðist t.d. við verðhækkunum með pví að velja ódýrari staðkvæmdarvöru. Einingarverð- 
teygni er pannig innbyggð í Jevons formúluna og aðferð sem pessi kemst nokkuð nálægt pví að ná fram kostum afburðavísitalnanna, án pess að fyrir liggi gögn til að meta nýjar vöruvogir sem eru nauðsynlegar til að reikna t.d. Fisher vísitölu. Niðurstaðan er sú að með pessari leið er verulega dregið úr staðkvæmdaráhrifum í vísitöluútreikningi og pau jafnvel upprætt að fullu í neðra lagi vísitölunnar (Diewert, Huwiler og Kohli, 2009).

Mögulegt er að meta staðkvæmdaráhrif fyrir ólíka vöruflokka út frá sögulegum gögnum og pannig er hægt að tilgreina pá vöruflokka sem helst verða fyrir pessum áhrifum. Við gerð verðvísitölu er pá mögulegt að taka mið af slíkum upplýsingum pegar vogir eru metnar og að leggja áherslu á að uppfæra reglulega vogir fyrir pessa flokka sem breytast hraðast ef gögnin til pess finnast. Slíkt getur pó krafist ýmissa ályktana og nauðsynlegt er að leiðréttingar af pessu tagi séu gerðar með gegnsæjum hætti. Í kjölfar hruns bankakerfisins á Íslandi á haustmánuðum 2008, sem óhjákvæmilega olli miklum breytingum á högum almennings í landinu, vaknaði umræða um skekkjur í mælingu Hagstofu Íslands á vísitölu neysluverðs. Var athyglinni beint að pví að ákveðnir vöruflokkar hefðu talsvert vægi í vísitölunni pó að eftirspurn eftir peim vörum væri ekki lengur til staðar og verð hefði hækkað mikið. Ef áhersla væri lögð á pað að uppfæra hratt vogir í efra lagi vísitölunnar færi umræða um staðkvæmdarvillur í vísitölunni hugsanlega ekki jafn hátt en pað sem er ekki jafn augljóst er að vandinn væri pá enn að miklu leyti til staðar. Ástæðan er sú að pó að veruleg leiðrétting yrði gerð á vogum á efra lagi vísitölunnar hefði pað ekki nema að litlu leyti áhrif á staðkvæmdarskekkju pví að hún verður að miklu leyti til í neðra lagi verðvísitölunnar. Í grein eftir Manser og McDonald (1988) er gert mat á staðkvæmdaráhrifum í verðbólgumælingum í Bandaríkjunum og pað borið saman við sambærilegar rannsóknir frá fyrri tíð. Höfundarnir telja að bjagi vegna staðkvæmdaráhrifa hafi verið vanmetinn og rekja pað til pess að í fyrri rannsóknum á pessum bjaga hafi gögnin sem unnið var með ekki verið greind jafn ítarlega í sundur. Með pví að greina gögnin í sundur í enn fleiri undirflokka en áður ná peir að leiðrétta staðkvæmdarbjaga í lægri lögum vísitölunnar og niðurstaða peirra er sú að stærðargráða metins bjaga eykst eftir pví sem vísitalan er greind niður í smærri einingar. Petta stafar af pví að staðkvæmdaráhrif koma fram í vali neytenda í lægstu lögum vísitölunnar par sem fólk velur t.d. matvöru sem ekki hefur hækkað eins mikið í verði og sú sem pað er vant að kaupa á meðan sú sem hefur hækkað vegur pyngra í vísitölunni en er ekki lengur keypt. Staðkvæmdaráhrifin eru pá til staðar í neðsta lagi allra flokka vísitölunnar svo lengi sem fyrrnefnd skilyrði um breytt verðhlutföll og tilvist staðkvæmdarvara séu fyrir hendi. Fyrir ólíka vöruflokka er mjög misjafnt hve hratt söluverð breytist pegar t.d. miklar gengisbreytingar verða og verð á vörum með háan veltuhraða breytist hugsanlega hraðar. Gengisbreyting kemur pví fyrr fram í innfluttri dagvöru og eldsneyti en pegar um er að ræða varanlegar neysluvörur eins og bíla og stór heimilistæki. Pess má geta að á vef Hagstofu Íslands voru birtar algengar spurningar og svör tengd vísitölu neysluverðs í kjölfar atburða haustsins 2008. Par kemur 
meðal annars fram að ef vog fyrir bíla hefði verið felld út úr vísitölunni hefði hækkun vísitölunnar á tímabilinu frá október 2008 til febrúar 2009 mælst 0,2\% hærri en ella (Hagstofa Íslands, á.á.).

\section{Hvernig er mati á vogum háttad í öðrum löndum?}

Hagstofur innan Evrópu og víðar vinna að miklu leyti eftir samhæfðu verklagi við gerð verðvísitalna pó að innan hvers lands ráđist endanleg útfærsla einnig af peim gögnum og aðföngum sem fyrir hendi eru. Alpjóðavinnumálastofnunin gefur út handbók um gerð neysluverðsvísitalna og að peirri útgáfu koma meðal annars fulltrúar Alpjóðagjaldeyrissjóðsins og Evrópsku hagstofunnar (Eurostat). Fulltrúar Hagstofu Íslands koma einnig að starfshópum um aðferðarfræði innan Evrópsku hagstofunnar og Ottawa hópsins, sem er samstarfsvettvangur sérfræðinga um verðvísitölur. ${ }^{1}$ Til að gefa mynd af breytileika aðferða milli ólíkra hagstofa eru hér teknar saman upplýsingar upp úr lýsigögnum og öðru birtu efni fyrir neysluverðsvísitölur nokkurra landa. Gera verður pann fyrirvara að oft eru lýsigögn ekki uppfærð um leið og aðferðafræði er breytt og lýsingar á aðferðum eru mis ítarlegar.

Hagstofan í Noregi metur vogir fyrir vísitölu neysluverðs með rannsókn á útgjöldum heimilanna og leggur til grundvallar niðurstöður priggja árlegra rannsókna. Vogirnar eru endurmetnar í ágústmánuði hvers árs og frá og með ágúst 2008 er byggt á niðurstöðum fyrir árin 2005 til 2007, p.e. reiknað er meðaltal pessara priggja ára en pað er sama aðferð og Hagstofa Íslands notar (Statistics Norway, 2001). Munurinn er sá að hér á landi er grunnurinn uppfærður 7 mánuðum síðar en gert er í Noregi en að öðru leyti eru aðferðirnar sambærilegar pegar horft er til útgjaldarannsóknanna. Í neðra lagi vísitölunnar var tekin upp notkun margfeldismeðaltals árið 1999 sem er sú formúla sem jafnan er beitt við útreikninginn hjá Hagstofu Íslands.

Í handbók finnsku hagstofunnar um útreikning vísitölu neysluverðs par í landi kemur eftirfarandi fram (Statistics Finland, 2008):

The consumer price index describes the price development of goods and services purchased by households in Finland, keeping the commodity basket and its weighting the same throughout the period calculated.

Vogum vísitölunnar er pví haldið föstum yfir útreikningstímann. Einnig kemur fram að vogir vísitölunnar eru endurskoðaðar á fimm ára fresti en að hugmyndir séu uppi um að uppfæra vogir árlega og er par vísað til Breta, Frakka og Svía sem hafa pann háttinn á. Núverandi vísitala var sett á 100 árið 2005 en vogirnar byggja á pjóðhagsreikningum ársins 2004 og par eru upplýsingar um einkaneyslu byggðar á rannsókn á útgjöldum heimila frá árinu 2001 (Statistics Finland, 2008). Pví eru vogir finnsku neysluverðsvísitölunnar byggðar á talsvert eldri gögnum en vogir peirrar íslensku.

1 Á vef Ottawa hópsins má nálgast fjölmargar rannsóknagreinar á sviði verðvísitalna. www.ottawagroup.org 
Samkvæmt gögnum af vef sænsku hagstofunnar er ólíkri aðferð beitt par. Í efsta lagi vísitölunnar, par sem yfirflokkar eru vegnir saman, er byggt á nýjum og reglulega uppfærðum gögnum um neyslu heimilanna. Fyrir vísitöluna hverju sinni er notast við gögn um neyslu frá árinu á undan en par sem tölur um veltu ársins eru ekki fullunnar fyrr en nokkru eftir að árið er liðið er fyrst um sinn byggt á mælingum fyrir prjá fjórðunga og spágildi fyrir pann fjórða. Pessar vogir byggja fyrst og fremst á tölum úr pjóðhagsreikningum um neyslu í Svípjóð. Í neðri lögum vísitölunnar eru yfirflokkarnir greindir frekar í sundur eftir niðurstöðum hefðbundinnar útgjaldarannsóknar (Statistics Sweden, 2001). Með pessu móti fást vogir í efsta lagi vísitölunnar uppfærðar mun hraðar en t.d. með peim aðferðum sem lýst var fyrir norsku og íslensku vísitöluna en vandinn er sá að gögnin eru ekki sundurgreind með sama hætti og ef um útgjaldarannsókn væri að ræða. Aðferð sem pessi byggir á góðu aðgengi að gögnum um heildarveltu yfirflokka vísitölunnar en sundurgreining pessara yfirflokka í aðrar vörur er gerð með eldri gögnum pví að gögn úr pjóðhagsreikningum liggja fyrir mun fyrr en niðurstöður nákvæmra útgjaldarannsókna. Pví er ekki komist hjá pví að gera útgjaldarannsókn af einhverju tagi meðal heimila til að meta vogir fyrir neðra lag vísitölunnar.

Írska hagstofan uppfærir grunn vísitölu neysluverðs með eigin rannsóknum á einkaneyslu, par með talinni útgjaldarannsókn meðal heimila. Slíkar rannsóknir eru framkvæmdar á fimm ára fresti og í handbók fyrir vísitölu neysluverðs par í landi frá ágúst 2008 kemur fram að á peim tímapunkti væri vísitalan byggð á grunni útgjaldarannsóknar sem gerð var á tímabilinu frá nóvember 2004 til desember 2005. Niðurstöður peirrar rannsóknar voru færðar á verðlag desembermánaðar 2006 og vísitalan svo sett á gildið 100 í peim mánuði. Af pessu má ætla að næsta útgjaldarannsókn nái yfir árið 2010 og að vísitala byggð á peim grunni verði birt árið 2012, sett á gildið 100 í desember 2011. Aðferðinni svipar til peirrar sem beitt er í Finnlandi og helsti munurinn á pessum tveim og peirri sem beitt er á Íslandi er að notast er við eitt ár frekar en meðaltal priggja ára og að vogin er uppfærð á 5 ára fresti en ekki árlega.

\section{Verðstöðugleiki}

Meginmarkmið peningamálastefnu víðast hvar í dag er að halda verðlagi stöðugu og sú skoðun er nú ríkjandi að verðbólga sé almennt skaðleg fyrir hagkerfið í heild, dragi úr varanlegum hagvexti, tefji sköpun nýrra starfa og skerði lífskjör (ECB bulletin, May 2008). Árangur landa við að halda aftur af verðbólgunni hefur verið misjafn gegnum árin enda búa löndin við ólíkar aðstæður. Einn augljós áhrifapáttur á verðstöðugleika hérlendis er sá að stór hluti neysluvara er innfluttur og verðlagður í annarri mynt en íslenskum krónum. Sveiflur á gengi krónunnar hafa pví talsverð áhrif á verðlag og fyrir vörur sem eiga sér fáar eða engar innlendar staðkvæmdarvörur koma gengisáhrifin fljótt fram. Tafla 1 sýnir lýsitölur fyrir verðbólgu í nokkrum Evrópulöndum, par á meðal peim sem horft var til í pessari grein. Lýsitölurnar eru unnar upp úr gögnum um samræmda vísitölu neysluverðs sem evrópska hagstofan 
birtir mánaðarlega. ${ }^{2}$ Byggt var á gögnum frá janúar 1996 til og með febrúar 2009 en pannig fást 158 mæligildi fyrir verðvísitöluna og 146 mælingar á verðbólgu yfir 12 mánaða tímabil. Af peim löndum sem litið er til í pessari grein hefur verðstöðugleiki verið áberandi minni á Íslandi og á Írlandi en að jafnaði hefur verðbólga hér verið 4,0\% ef reiknað er margfeldismeðaltal yfir fyrrnefnt tímabil. Par sem verðbólga mælist jafnan há er hún einnig sveiflukenndari, p.e. verðbólguskot eru tíð. Petta á sérlega við hérlendis pví að gengisskellir hafa verið tíðir og peir valda ekki eingöngu verðbólguskotum heldur einnig pví að verðhlutföll breytast hratt.

Tafla 1. Lýsitölur fyrir verðbólgu í nokkrum Evrópulöndum á árunum 1996 til 2009.

\begin{tabular}{rccccccc}
\hline & Danmörk & Pýskaland & Írland & Finnland & Svípjóð & Ísland & Noregur \\
\hline Hágildi & 4,8 & 3,5 & 6,0 & 4,7 & 4,2 & 21,9 & 5,1 \\
Miðgildi & 2,0 & 1,5 & 2,7 & 1,4 & 1,4 & 2,6 & 2,0 \\
Lággildi & 0,4 & 0,1 & 0,1 & $-0,4$ & $-0,1$ & 0,2 & $-1,5$ \\
Meðaltal & 2,0 & 1,6 & 3,0 & 1,7 & 1,6 & 4,0 & 1,9 \\
\hline
\end{tabular}

Í landi með opið hagkerfi og smáan fljótandi gjaldmiðil má alltaf búast við gengissveiflum og óstöðugu verðlagi. Oft hefur verið nefnt að með aðild Íslands að stærra myntsvæði, t.d. með upptöku evru hérlendis, næðist meiri verðstöðugleiki. Í aðdraganda stofnunar evrópska myntsvæðisins dró úr breytileika í verðbólgu milli verðandi aðildarlanda og stöðugleiki komst par á. Verðstöðugleiki er einnig eitt af skilyrðunum fyrir inngöngu nýrra aðila að myntbandalaginu. คó er pað ekki svo að verðbólga sé sú sama meðal landa myntsvæðisins heldur er ennpá munur á verðlagi milli landanna og pað er eðlilegt að verðbólga sé einnig mismikil. Ólík verðpróun stafar meðal annars af leiðréttingu verðhlutfalla sem fylgir stofnun myntsvæðisins, t.d. vegna aðlögunar raunlauna en einnig vegna pátta eins og mishröðum vexti í framleiðni milli landanna (í grein Angeloni og Ehrmann (2004) er fjallað um ýmsar orsakir breytilegrar verðpróunar innan myntbandalagsins). Verðstöðugleiki myndi færast nær pví sem pekkist innan myntbandalagsins ef Ísland gerðist aðili að pví.

\section{Mat á bjaga vegna staðkvæmdaráhrifa}

Mat á bjaga vegna staðkvæmdaráhrifa verður ekki gert öðruvísi en með hagmælingum. Til pess að mæla bjaga t.d. Laspeyres verðvísitölu parf hið sanna gildi sem vísitölunni er ætlað að mæla að vera pekkt. Pegar um er að ræða t.d. vísitölu neysluverðs pá er sú vísitala auðvitað ekki fyrir hendi eins og áður var rætt en hins vegar má með ýmsum aðferðum meta raunverulegar breytingar framfærslukostnaðar og fá pannig mat á pví hve mikill bjaginn er. Laspeyres og Paasche vísitöluformúlurnar gefa efri og neðri mörk fyrir raunverulega framfærsluvísitölu en að gefnum vissum

2 Gögnin má nálgast á vef Evrópsku hagstofunnar:

http://epp.eurostat.ec.europa.eu/portal/page/portal/hicp/introduction 
forsendum um samband verðbreytinga og neysluhegðunar má ætla að afburðavísitala eins og t.d. Fisher vísitala gefi gott mat á raunverulegri próun framfærslukostnaðar. Diewert, Huwiler og Kohli (2009) meta staðkvæmdaráhrif í vísitölu neysluverðs í Sviss með pví að reikna vísitöluna til baka með Fisher formúlu yfir tímabilið frá 1993 til 2000 og peirra mat er að staðkvæmdaráhrif í efra lagi hafi hækkað vísitöluna um 0,13\% á ári að jafnaði. Sú niðurstaða er keimlík peirri sem birt var í Boskin skýrslunni par sem staðkvæmdaráhrif í efra lagi vísitölu neysluverðs í Bandaríkjunum voru metin 0,15\%. Í eldri greinum (Manser og McDonald, 1988 og Aizcorbe og Jackman, 1993) höfðu áhrifin verið metin nálægt 0,2\% og Hill (2006) tekur saman nokkrar rannsóknir til viðbótar sem meta áhrifin á bilinu milli 0,15\% og 0,25\%. Ætla má að staðkvæmdaráhrif í vísitölu neysluverðs hérlendis séu ekki ósvipuð. Oft hefur verðbólga á Íslandi mælst tiltölulega há og lítill verðstöðugleiki getur valdið pví að staðkvæmdaráhrifin verði meiri en ella en á móti kemur að dregið er úr áhrifunum með pví að færa t.d. tímanlega inn nýjar upplýsingar um neyslu pegar vogir vístölunnar eru metnar. Eins og fram hefur komið getur bjagi í vísitölunni orsakast af peirri útreikningsaðferð sem valin er. Evrópska hagstofan (Eurostat) birtir mánaðarlega samræmda vísitölu neysluverðs til að mæla á samanburðarhæfan hátt verðbreytingar innan EES. Par hefur Eurostat einfaldlega lagst gegn notkun ákveðinna formúla vegna pess bjaga sem fylgir notkun peirra en tekið fram aðrar sem eru leyfðar, par á meðal Jevons formúlu sem er einmitt byggðá margfeldismeðaltali.

\section{Niðurstöður}

Раð er vandkvæðum bundið að mæla breytingar á verðlagi einkaneyslu með vísitölu sem byggir á fastri vörukörfu. Neytendur bregðast við verðbreytingum með pví að neyta annarra vara en peir hefðu ella gert og kallar pað fram bjaga í mælingu neysluverðs sökum staðkvæmdaráhrifa. Vandamálið sem fylgir notkun Laspeyres gerðar af vísitöluformúlu hefur pekkst síðan snemma á 20. öldinni en nú hafa að mestu verið fundin ráð við vandanum, meðal annars með notkun vegins margfeldismeðaltals í neðsta lagi neysluverðsvísitalna. Staðkvæmdaráhrif eru pó enn að einhverju leyti til staðar, helst innan vöruflokka par sem verðhlutföll breytast hratt og par sem framboð staðkvæmdarvara er nægt. Lagt hefur verið mat á staðkvæmdaráhrif í neysluverðsvísitölum ýmissa landa og algengt er að verðbólga sé talin ofmetin um nálægt $0,2 \%$ á ári vegna pessa. Álykta má að staðkvæmdaráhrif í vísitölu neysluverðs hérlendis séu pau sömu, eða um 0,2\% á árs grundvelli að jafnaði. Bjagi vegna staðkvæmdaráhrifa er ekki föst stærð heldur er hann háður páttum sem eru breytilegir frá einum tíma til annars. Óstöðugt verðlag hefur áhrif til aukningar staðkvæmdaráhrifa og í samanburði við pau lönd og pær rannsóknir sem horft var til í pessari grein pá er verðstöðugleiki á Íslandi lítill. Á móti kemur að grunnur vísitölu neysluverðs hérlendis er metinn árlega en víða er slíkt endurmat framkvæmt sjaldnar og með eldri gögnum. 
Með tíðri endurskoðun á grunni vísitölunnar má fylgja neyslubreytingum betur eftir og dregur pað úr staðkvæmdaráhrifum.

\section{Um höfundinn}

Kári Joensen er aðjúnkt við Viðskiptadeild Háskólans á Bifröst og hagfræðingur við Rannsóknasetur verslunarinnar. Netfang: kari@bifrost.is.

\section{Heimildaskrá}

Aizcorbe, A.M. og Jackman, P.C. (1993). The commodity substitution effect in CPI data, 198291. Monthly Labor Review 116 (12), 25-33.

Angeloni, I. og Ehrmann, M. (2004). Euro area inflation differentials. European Central Bank working paper no. 388, September 2004.

Balk, B. og Diewert, W.E. (2003). The Lowe consumer price index and its substitution bias. Department of Economics, University of British Columbia, discussion paper 04-07, December 2003. Slóð: http://www.econ.ubc.ca/discpapers/dp0407.pdf

Boskin, M.J., Dulberger, E.R., Gordon, R.J., Griliches, Z. og Jorgenson, D. (1996). Towards a more accurate measure of the cost of living. Final report to the Senate Finance Committee from the Advisory Commission to Study the Consumer Price Index.

Dalton, K.V., Greenlees, J.S. og Stewart, K.J. (1998). Incorporating a geometric mean formula into the CPI. Monthly Labor Review, 121 (10), 3-7.

Diewert, W.E. (1976). Exact and superlative index numbers. Journal of Econometrics, 4 (2), 115145.

Diewert, W.E., Huwiler, M. og Kohli, U. (2009). Retrospective price indices and substitution bias. Department of Economics, University of British Columbia, discussion paper 09-01. Slóð: http://www.econ.ubc.ca/diewert/dp0901.pdf

Greenlees, J.S. (1998). Expenditure weight updates and measured inflation. Bls. 57-64 í B.M. Balk (ritsti.) Proceedings of the third meeting of the international working group on price indices. Statistics Netherlands.

Hagstofa Íslands (2008a). Vísitala neysluverðs. (Lýsigögn á vef Hagstofunnar undir flokknum Verðlag og neysla. Uppfært 26. janúar 2008.) Sótt 23. febrúar 2009 af http://hagstofa.is/pages/349

Hagstofa Íslands (2008b). Vísitala neysluverðs apríl 2007-2008. Hagtíðindi, 93 (35). Slóð: https://hagstofa.is/lisalib/getfile.aspx?ItemID=8138

Hagstofa Íslands (2009). Vísitala neysluverðs apríl 2008-2009. Hagtíðindi, 94 (32). Slóð: https://hagstofa.is/lisalib/getfile.aspx?ItemID=9691

Hagstofa Íslands (á.á.). Spurningar og svör um vísitölu neysluverðs. (Vefsíða.) Sótt 27. mars 2009 af http://hagstofa.is/pages/2249

Hill, R.J. (2006). Superlative index numbers: Not all of them are super. Journal of Econometrics, $130(1), 25-43$.

Manser, M.E. og McDonald R.J. (1988). An analysis of substitution bias in measuring inflation, 1959-85. Econometrica, 56 (4), 909-930. 
Rannsóknasetur verslunarinnar (2009). Mikill samdráttur var í verslun í febrúar. Frétt á vefsíðu, 12. mars. Sótt 14. júlí 2009 af http://rsv.bifrost.is/Default.asp? fre_id $=84876 \&$ meira $=1$

Rósmundur Guðnason. (2004). Hvernig mælum við verðbólgu? Fjármálatíðindi, 51 (1), 33-54.

Schmidt, M.L. (1995). Comparing market basket changes and the CPI. Bls. 121-126 í American Statistical Association, Proceedings of the Social Statistics Section. Slóð: http://www.bls.gov/ore/pdf/st950200.pdf

Statistics Finland (2008). Consumer price index 2005=100: Handbook for users. (Statistics Finland handbook 39c.) Helsinki: Statistics Finland. Slóð: http://www.stat.fi/tup/julkaisut/isbn_978-952-467-924-4.pdf

Statistics Norway (2001). Konsumprisindeksen 1995-2000. Osló: Statistisk sentralbyrå. Slóð: http://www.ssb.no/emner/08/02/10/nos_c680/nos_c680.pdf

Statistics Sweden (2001). The Swedish consumer price index: A handbook of methods.

Stokkhólmur: Statistiska Centralbyrån. Slóð:

http://www.scb.se/statistik/PR/PR0101/handbok.pdf 